\title{
Mengoptimalkan Peran Badan Perfilman Indonesia: Analisis Aspek Hak Cipta terhadap Praktik Siaran Video Ilegal
}

\author{
Relys Sandi Ariani* \\ University of Brawijaya, Malang, Indonesia
}

\section{Luna Dezeana Ticoalu \\ University of Brawijaya, Malang, Indonesia}

\section{Herlin Sri Wahyuni \\ University of Brawijaya, Malang, Indonesia}

\begin{abstract}
The film is part of the intellectual property rights attached to the creator. Nowadays, it is commonly agreed that violation of intellectual property rights portrays in film piracy for personal gain is inevitable, with illegal streaming services. This study aimed to examine film protection, conduct a study of film institutions, and find concepts to protect films in Indonesia. The study used a juridical method with the statute and conceptual approaches. In so doing, it used secondary data processed using library research techniques. The study showed that illegal movie streaming rampant in Indonesia practiced illegal streaming movies. It violated the intellectual property rights inherent in the creator, resulting in enormous losses for the creators. There are further problems in the laws and regulations, and the government must accommodate preventive actions. This study suggested three components: correctional, supervision, and copyright protection against illegal movie streaming in Indonesia; and these components were to maximize the role of stakeholders.
\end{abstract}

KEYWORDS: Illegal Streaming Movies, Indonesian Film Institute, Intellectual Property Rights and Copyrights.

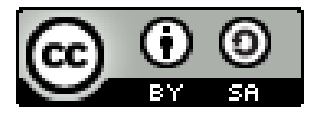

Copyright (C) 2021 by Author(s)

This work is licensed under a Creative Commons Attribution-ShareAlike 4.0 International License. All writings published in this journal are personal views of the authors and do not represent the views of this journal and the author's affiliated institutions.

\section{HOW TO CITE:}

Ariani, Relys Sandi, et al., "Mengoptimalkan Peran Badan Perfilman Indonesia: Analisis Aspek Hak Cipta terhadap Praktik Siaran Video Ilegal" (2021) 1:2 Jurnal Kajian Pembaruan Hukum 175-214. DOI: <https://doi.org/10.19184/jkph.v1i2.24475>.

Submitted: 01/06/2021 Reviewed: 06/06/2021 Revised: 12/07/2021 Accepted: 27/07/2021

\footnotetext{
*Corresponding authors' e-mail: relysandi@gmail.com
} 


\section{PENDAHULUAN}

Kekayaan intelektual dapat didefinisikan sebagai hak eksklusif yang diberikan negara pada kretor, inventor atau pendesain atas hasil kreasi yang ciptakan atau hasil temuannya yang mempunyai nilai komersial secara otomatis melalui pendaftaran pada instansi terkait sebagai penghargaan dan pengakuan hak yang patut diberikan perlindungan hukum. ${ }^{1}$ menciptakan suatu karya bukanlah sesuatu hal yang mudah. Karena, karya yang di ciptakan atau dihasilkan atas kemampuan intelektual manusia baik melalui tenaga, pikiran dan daya cipta, rasa serta karsanya sehingga hal ini sudah sepatutnya untuk dilindungi hukum atas kekayaan tersebut yang dikenal sebagai sistem Hak Kekayaan Intelektual (selanjutnya disebut HKI).

HKI merupakan sesuatu yang harus dimiliki oleh setiap orang baik sejak lahir dan meninggal, hal tersebut dengan cara melindungi kekayaan intelektual dengan menggunakan kententuan-ketentuan hukum yang ada baik itu hak cipta, hak paten, merek dan indikasi geografis, rahasia dagang, desain industri, desain tata letak Sirkuit terpadu, dan perlindungan varietas tanaman. Untuk memahami kekayaan intelektual dan HKI secara ringkas atau sederhana dapat dilihat sebagai berikut :

1 S Mulayani, "Pengembangan Hak Kekayaan Intelektual Sebagai Collateral (Agunan) Untuk Mendapatkan Kredit Perbankan Di Indonesia" (2012) 12:3 J Din Huk 568-578 at 568. 


\section{Gambar 1. Cara sederhana pemahaman kekayaan Intelektual dan} HKI

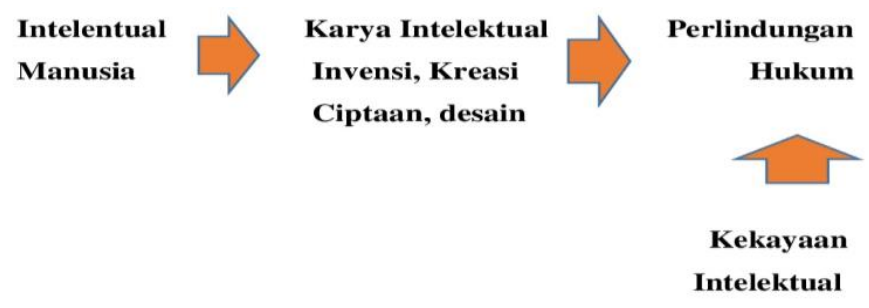

\section{Sumber : Kreasi Penulis}

Berdasarkan uraian di atas, dapat dipahami secara sederhana bahwa HKI merupakan hak yang berasal dari karya, karsa, dan daya cipta dari kemampuan intelektualitas manusia yang memiliki manfaat serta mempunyai nilai guna secara ekonomis dalam menunjang kehidupan sehari-harinya. Bentuk nyata dari hasil intelektual tersebut dapat berupa ilmu pengetahuan, teknologi, seni dan sastra. Adanya perkembangan zaman teknologi baru memberikan potensi bagi pemegang hak cipta dalam mempromosikan karya-karya terbaik mereka untuk alasan artistik, pendidikan, dan komersial. ${ }^{2}$ Namun, dengan kemunculan teknologi baru dapat mengakibatkan adanya pelanggaran hak cipta dikarenakan tersedianya cara cepat, mudah, dan tidak berbayar untuk menyebarkan film-film yang ada. Survei yang dilakukan oleh perusahaan data dan opini publik global menemukan bahwa di tengah-tengah booming layanan streaming online, mayoritas penduduk Indonesia lebih memilih menonton melalui situs web illegal. ${ }^{3}$

HKI merupakan hak privat (private rights) bagi seseorang yang menghasilkan suatu karya intelektual. ${ }^{4}$ Oleh karena itu, setiap orang

2 Wilson Vernando et al, "Pengaruh Illegal Movie Streaming Terhadap Popularitas Film Bagi Mahasiswa" (2020) 6:1 J Teknol Inf 35-42 at 38.

3 Ibid at 40.

4 K Setyowati, "Implementasi Sistem hak Kekayaan Intelektual (HKI) Pada Pengelolaaan Plasma Nutfah" (2002) 8:2 Bul Plasma Nutfah 90-101 at 97. 
wajib menghormati keberadaan pencipta serta diperlukanya sebuah pengakuan dari segi hukum untuk melindungi karya tersebut. ${ }^{5}$ Karena, HKI sebagai seperangkat aturan yang mengatur tentang perlindungan hukum terhadap pencipta atas karya ciptanya serta penemu karya inovatif. Ditinjau dari Peraturan PerundangUndangan HKI beberapa sudah memiliki payung hukum yang sudah tertuang diantaranya yaitu, Undang-Undang Nomor 14 Tahun 2001 Tentang Paten, Undang-Undang Nomor 15 Tahun 2001 tentang Merek, dan Undang-Undang Nomor 28 Tahun 2014 Tentang Hak Cipta.

Secara legitimasi hukum, ketiga Perundang-undangan tersebut menjadi hak atas HKI yang paling umum digunakan dalam bisnis. Namun, dari tiga pengaturan HKI tersebut hak melindungi aspek yang berbeda - beda. Dari pengertian ketiga HKI tersebut, disini hak merek yaitu memberikan perlindungan atas merek dagang dan jasa yang dimiliki, hak paten yaitu memberikan pengakuan kepada penemu atas temuannya yang dapat diterapkan dalam industri. sedangkan, untuk memberikan hak eksklusif atas suatu ciptaan, baik secara moral maupun memiliki nilai ekonomis untuk yang telah maupun belum diterbitkan hal tersebut di sebut dengan hak cipta. Saat ini, salah satu permasalahan hak cipta yang sedang ramai dibicarakan di tengah pandemi yaitu pelanggaran hak cipta atas hak ekonomi pada perfilm di Indonesia.

Contoh konkrit adalah peningkatan jumlah movie illegal streaming yang hal ini berdampak pada industri film dan pendapatan Negara Indonesia, yaitu pada kasus movie illegal streaming di Kecataman Jambi yang dilakukan oleh Aditya Fernando Phasyah, terbukti

5 Gatot Supramono, Hak cipta dan aspek-aspek hukumnya (Jakarta: Rineka Cipta, 2010) at 61. 
dinyatakan bersalah melakukan movie illegal streaming pada film Keluarga Cemara milik rumah produksi Visinema Pictures, yang di platform website Dunia Film 21. Tidak hanya itu saja Aditya Fernando Phasyah telah melakukan sekitar movie illegal streaming 3.000 judul film lokal dan import sejak tahun 2018 hingga saat ini untuk mencari keuntungan dari iklan yang didaftarkan. ${ }^{6}$ Maraknya movie illegal streaming yang dilakukan masyarakat, hal ini dapat merugikan para pelaku industri film karena tidak mendapatkan pendapatan yang menjadi haknya ketika sebuah film diputar ataupun disaksikan oleh banyak orang, apabila permasalahan tersebut berlangsung lama dapat mempengaruhi produksi film baik secara pengeluaran karena menyerap banyak tenaga kerja.

Karya cipta seni budaya yang menjadi pranata sosial dan media komunikasi massa yang berdasarkan kaidah sinematografi dengan atau tanpa suara dan dapat dipertunjukkan sebagai sebuah karya cipta, yang disebut dengan pengertian film itu sendiri. Berdasarkan Undang-Undang Hak Cipta (selanjutnya disebut UUCH) Nomor 28 Tahun 2014 Tentang Hak Cipta menjelaskan bahwa hak cipta adalah hak eksklusif pencipta yang timbul secara otomatis berdasarkan prinsip deklaratif setelah suatu ciptaan diwujudkan dalam bentuk nyata tanpa mengurangi sesuai dengan peraturan perundangundangan. Hak cipta ini biasanya sering berlaku untuk beberapa jenis karya seni atau karya cipta seperti puisi, drama, karya tulis, lukisan, patung, lagu, film, dan sebagainya.

Hak Cipta terdiri atas hak ekonomi dan hak moral. Hak ekonomi adalah hak untuk mendapatkan manfaat ekonomi atas ciptaan serta

6 Gresi Plasmanto, “Jejak Seorang Gamers Jadi Pembajak Film Keluarga Cemara", (2021), online: Liputan6.com <https://www.liputan6.com/regional/read/4548779/jejak-seorang-gamersjadi-pembajak-film-keluarga-cemara>. 
produk hak terkait sedangkan hak moral adalah hak yang ada dalam diri pencipta dan tidak dapat dihilangkan, artinya hak tersebut melekat selama hidup pencipta bahkan hingga setelah meninggal dunia. ${ }^{7}$ film merupakan bagian dari kekayaan intelektual yang harus dilindungi, hal ini terdapat pada Undang-Undang Nomor 28 Tahun 2014 Tentang Hak Cipta pada pasal 40 ayat (1) yang menjelaskan bahwa ciptaan yang dilindungi meliputi ciptaan dalam bidang ilmu pengetahuan, seni, dan sastra, salah satunya yaitu pada huruf $\mathrm{m}$ yaitu karya sinematograh. Pengertian karya sinematografi adalah ciptaan yang berupa gambar bergerak (moving images) antara lain film dokumenter, film iklan, reportase atau film cerita yang dibuat dengan skenario, dan film kartun. Karya sinematografi dapat dibuat dalam pita seluloid, pita video, piringan video, cakram optik dan/atau media lain yang memungkinkan untuk dipertunjukkan di bioskop, layar lebar, televisi, atau media lainnya. ${ }^{8}$

Pada dasarnya HKI merupakan hal melekat pada diri pencipta yang harus dilindungi secara hukum. Maka, bagi seorang pembuat film selaku pemilik hak cipta atas karya film memiliki hak eksklusif yaitu hak untuk mendominasi atas karya ciptaanya dalam rangka melindungi karya ciptanya dari pihak lain seperti hak untuk mengumumkan dan memperbanyak karya ciptannya atau memberikan izin kepada orang lain untuk mendapat keuntungan secara ekonomis. ${ }^{9}$

7 Budi Santoso, HKI Hak Kekayaan Intelektual, 2d ed (Semarang: Pustaka Magister, 2011) at 27.

8 Vide. Undang-Undang Nomor 28 Tahun 2014 Tentang Hak Cipta Pasal 4040 ayat (1) yang menjelaskan bahwa ciptaan yang dilindungi meliputi ciptaan dalam bidang ilmu pengetahuan, seni, dan sastra, salah satunya yaitu pada huruf m yaitu karya sinematograh.

9 Yusran Isnaini, Buku pintar HAKI tanya jawab seputar Hak Kekayaan Intelektual (Bogor: Ghalia Indonesia, 2010) at 39. 
Berdasarkan pemaparan data diatas mengenai banyaknya oknum yang tidak bertanggung jawab mengambil sebuah keuntungan secara pribadi dengan cara melakukan pelanggaran hak cipta pada film yang telah diumumkan dan mendapatkan apresiasi yang baik dari penonton. Canggihnya teknologi saat ini dapat di manfaatkan untuk hal-hal kejahatan. Seperti saat ini cara yang dilakukan oleh pembajak tidak lagi ke dalam bentuk kepingan VCD/DVD, tetapi dengan menggunakan internet untuk memasukkan film tersebut ke dalam situs penyedia layanan film streaming secara gratis, yang hal ini merupakan suatu tindakan yang melanggar hak cipta terhadap movie illegal streaming di Indonesia.

Tindakan ini dibuktikan pada bulan Januari 2020 lalu, Kementerian Komunikasi dan Informatika (selanjutnya disebut Kemkominfo) memblokir situs streaming film ilegal yang banyak digunakan orang, diantaranya yaitu IndoXXI, Nonton Movie, Juragan Film, LK21 atau LayarKaca21, Gudangfilm, CinemaIndo, dan beberapa situs streaming film online lainnya, ${ }^{10}$ sudah diblokir oleh pemerintah akibat melanggar hak cipta dan tidak membayar royalti ke pembuat film. Menurut Menteri Kominfo, Johnny G. Plate, mengatakan bahwa situs-situs seperti IndoXXI itu melanggar kekayaan intelektual pembuat film, sehingga harus ditutup.

Movie Streaming secara gratis di internet dapat merugikan pemegang hak cipta film dikarenakan pengguna (user) dapat mengunduh film tanpa harus meminta ijin dan membayar sebagaimana layaknya jika

10 Kementerian Komunikasi dan Informatika Republik Indonesia, "22 Situs Diduga Pembajak Film Diblokir Kemenkominfo", (2015), online: $<$ https://kominfo.go.id/content/detail/5651/22-situs-diduga-pembajak-filmdiblokir-kemenkominfo/0/sorotan_media>. 
menonton film dibioskop. ${ }^{11}$ Deputi Fasilitasi Hak Kekayaan Intelektual (HKI) dan Regulasi Bekraf, Ari Juliano Gema, mengatakan Indonesia masuk 10 (Sepuluh) besar negara dengan angka pembajakan tinggi. Munculnya situs-situs nonton movie streaming ini tidak lepas dari tingginya trafik ke situs, apalagi pada situasi pandemi COVID-19 kebanyakan masyarakat Indonesia menghabiskan waktu dirumah aja bersama keluarga dengan menonton film.

Indonesia memang pasar movie streaming illegal, menurut survei terbaru yang dirilis YouGov, merupakan perusahaan riset dan analisis data film yang dipublikasikan pada Desember 2019, menyebutkan bahwa 63 persen konsumen daring di Indonesia menonton situs streaming ilegal atau situs torrent. ${ }^{12}$ Apabila mengacu pada survei Asosiasi Penyelenggara Jasa Internet Indonesia periode 2019 - kuartal kedua 2020, pengguna internet di Indonesia 196,7 juta jiwa. Sehingga, jumlah pengguna yang terlibat dalam permodelan pembajakan ini 110 sampai 125 juta pengguna. Para pengguna layanan ilegal tersebut menggunakan berbagai media, dari situs hingga aplikasi. Bahkan 44 responden berusia 18 hingga 24 tahun mengaku menggunakan layanan ilegal tersebut. ${ }^{13}$ Akibat dari pembajakan tersebut, Ketua Asosiasi Produser Film

11 Hendrianto, "Perlindungan Hukum Bagi Pemegang Hak Cipta Film Dari Kegiatan Streaming dan Download Pada Website Illegal" (2019) 6:1 JOM Fak Huk Univ Riau 1-15 at 11.

12 Hidayat Setiaji, "Serupa IndoXXI, Situs Ini Punya Koleksi Melebihi Netflix!", (2019), online: CNBC Indones $<$ https://www.cnbcindonesia.com/tech/20191224185849-37-125487/serupaindoxxi-situs-ini-punya-koleksi-melebihi-netflix>.

13 Luki Safriana, "Kembali ke Bioskop dan Upaya Melawan Pembajakan di Era Internet", (2021), online:

Katadata $<$ https://katadata.co.id/muchamadnafi/indepth/6062929b63666/kembali-kebioskop-dan-upaya-melawan-pembajakan-di-era-internet>. 
Indonesia (APROFI) yaitu Edwin Nazir mengalami kerugian industri film indonesia meningkat mencapai 5 (lima) triliun pertahuannya. ${ }^{14}$ Sedangkan, menurut Kominfo, pada Desember 2019 berupaya meredam pembajakan konten, termasuk film, dengan memblokir situs-situs movie illegal streaming dengan total 1.745 situs dan konten termasuk didalamnya film illegal pun belum cukup. ${ }^{15}$

Jika melihat kominfo dan oknum yang tidak bertanggung jawab bak berkejaran dalam arena yang tak berujung selesai, dari dua belah pihak tersebut terus berulang dan tak juga mencapai babak final. Salah satunya adalah situs streaming film ilegal seperti IndoXX1 dan LK21 dengan turunannya. Contoh konkrit, tindakan movie illegal streaming juga terdapat dalam aplikasi pengirim pesan. Ironisnya, pemerintah Indonesia bingung menghadapi permasalahan terhadap pembajakan di Indoneia. Menurut Menteri Kominfo Republik Indonesia Rudiantara mengaku tak tahu harus melakukan apa, meskipun perangkat teknologi dan informasi seharusnya berada di bawah kendalinya. Karena, disini netizen Indonesia lebih pandai dalam mempermudah pembajakan dan akses mendapatkannya di era digital ini.

Cara kerja dari pembajakan film melalui aplikasi pengirim pesan itu adalah dengan mengirimkan tautan streaming ilegal tersebut ke ruang pesan yang nantinya dikirimkan kepada orang-orang yang menggunakan aplikasi tersebut, salah satunya adala melalui aplikasi

${ }^{14}$ AntaraNewscom, "Babak baru perlawanan industri film Indonesia terhadap pembajakan", online: $<$ https://www.antaranews.com/berita/1826376/babak-baru-perlawananindustri-film-indonesia-terhadap-pembajakan>.

15 Ibid. 
Telegram. $^{16}$ Selain itu, contoh kasus pembajakan film yaitu pembajakan film Warkop DKI Reborn yang tersangkanya merupakan seorang wanita yang merekam lansung di bioskop ketika menonton film Warkop DKI dan pelaku mengunggah di aplikasi bigo, tentu hal tersebut merupakan tindakan yang tidak bertanggung jawab dalam mendapatkan keuntungan diri sendiri dengan cara mengambil suatu hasil karya tanpa seizin yang memilikinya. sedangkan aktivitas pembajakan film tersebut dapat mengakibatkan penurunan terhadap kreativitas dan semangat cipta para insan film dan menghambat perkembangan ekonomi kreatif yang menjadi salah satu andalan Indonesia yang saat ini cukup memegang peranan yang penting bagi pendapatan Negara.

Akibat dari maraknya kegiatan download atau melakukan movie ilegal streaming pemerintah telah menderita kerugian kurang lebih mencapai empat (4) triliun rupiah. Padahal, berdasarkan Undangundang Nomor 11 Tahun 2008 Tentang Informasi serta Transaksi Elektronik perubahan atas Undang-Undang Nomor 19 Tahun 2016 pada pasal 26 ayat (1) mengatakan " kecuali ditentukan lain oleh Peraturan Perundang-undangan, penggunaan setiap informasi melalui media elektronik yang menyangkut data pribadi seseorang harus dilakukan atas persetujuan Orang yang bersangkutan." Sedangkan, pada ayat (2) menjelaskan "Setiap Orang yang dilanggar haknya sebagaimana dimaksud pada ayat 1 dapat mengajukan gugatan atas kerugian yang ditimbulkan berdasarkan undangundang ini". ${ }^{17}$ Maraknya pembajakan film dan masyarakat movie

${ }^{16}$ H Astuti, R Marpaung, D, S, "Perlindungan Hukum Terhadap Pemegang Hak Cipta Terkait Pembajakan Sinematografi di Aplikasi Telegram" (2021) 27:7 J Ilm Ilmu Huk 992-1006 at 1000.

17 Vide. “Undang-undang Informasi Undang-undang Nomor 11 Tahun 2008 Tentang Informasi serta Transaksi Elektronik perubahan atas Undang- 
illegal streaming yang dapat merugikan para pelaku industri film sekaligus mempengaruhi produksi film karena menyerap banyak tenaga kerja. Menurut Ketua APROFI, yaitu Edwin Nazir mengungkapkan setelah Bioskop tutup, produksi film diberhantikan karena adanya pandemi COVID-19 yang berdampak kerugian sebesar $80 \%$ di tahun $2020 .{ }^{18}$

Dari pemaparan problematika mengenai maraknya pembajakan yang dilakukan oleh oknum yang tidak bertanggung jawab dan trafik tingginya masyarakat melakukan movie illegal streaming di tengah pandemi COVID-19 yang dapat merugikan para pelaku industri film dan pemerintah sebagai pendapatan Negara dalam bidang perekonimian di Indonesia, ironisnya lagi Menteri Kominfo Republik Indonesia Rudiantara mengaku tak tahu harus melakukan apa terhadap pembajakan yang dilakukan oknum yang tidak bertanggung jawab. Maka, untuk melindungi hak cipta dalam industry perfilman dan membantu pemerintah khusunya Kominfo penulis menggagas konsep yaitu Mengoptimalkan Peran Badan Perfilman Indonesia: Analisis Aspek Hak Cipta terhadap Praktik Siaran Video Ilegal.

Konsep ini menggunakan tiga komponen yaitu pemasyarakatan, pengawasan, dan dan perlindungan terhadap hak cipta tehdap movie

Undang Nomor 19 Tahun 2016".pada pasal 26 ayat 1 mengatakan “ketentuan lain oleh Peraturan Perundang-undangan, penggunaan setiap informasi melalui media elektronik yang menyangkut data pribadi seseorang harus dilakukan atas persetujuan Orang yang bersangkutan." Sedangkan, pada 2 menjelaskan "Setiap Orang yang dilanggar haknya sebagaimana dimaksud pada ayat 1 dapat mengajukan gugatan atas kerugian yang ditimbulkan berdasarkan undang-undang ini"

18 CNBC Indonesia, "Derita Industri Film RI Bila Kamu Nggak Tobat Nonton Bajakan", online: $<$ https://www.cnbcindonesia.com/tech/20210115172226-37-216396/deritaindustri-film-ri-bila-kamu-nggak-tobat-nonton-bajakan>. 
illegal streaming di Indonesia. Harapannya konsepan ini dapat membantu Kominfo dalam memberantas oknum yang tidak bertanggung jawab terhadap pembajakan dengan memaksimalkan peran stekeholder dengan meminimalisir terjadinya movie streaming illegal dan sekaligus untuk menguatkan perlindungan pada hak cipta dalam industri film yang dibuatnya dan dapat meningkatkan pendapatan Negara melalui karya di industri perfilman di Indonesia.

\section{METODE}

Penelitian ini menggunakan metode penelitian hukum normatif atau yuridis normatif dengan menelaah bahan pustaka atau data sekunder. ${ }^{19}$ Metode pendekatan yang digunakan dalam penelitian ini adalah: 1) Pendekatan perundang-undangan ${ }^{20}$ (statute-approach), yaitu dengan menelaah peraturan perundang-undangan yang berkaitan dengan perlindungan hak cipta di Indonesia; 2) Pendekatan konseptual (conseptual approach), ${ }^{21}$ yaitu dengan menelaah terkait permasalahan perlindungan hak cipta terhadap movie illegal streaming di Indonesia.

Jenis data yang digunakan dalam penelitian adalah data sekunder sebagai data utama, yang terdiri dari: a) Bahan hukum primer yakni peraturan perundang-undangan yang meliputi: 1) Undang-Undang Dasar Negara Republik Indonesia Tahun 1945; 2) Undang-Undang Nomor 32 Tahun 2002 tentang Penyiaran; 3) Undang-Undang Nomor 33 tahun 2009 tentang Perfilman; 4) Undang-Undang Nomor 28

19 Sri Mamudji Soerjono Soekanto, Penelitian hukum normatif: suatu tinjauan singkat, 17th ed (Jakarta: Rajawali Pers, 2015) at 29.

20 Peter Mahmud Marzuki, Penelitian Hukum (Jakarta: Kencana, 2007) at 66.

21 Johnny Ibrahim, Teori dan metode penelitian hukum normatif (Malang: Bayumedia Publishing, 2005) at 60. 
Tahun 2014 Tentang Hak Cipta; 5) Undang-Undang Nomor 19 Tahun 2016 Tentang Perubahan atas Undang-Undang Nomor 11 Tahun 2008 Informasi Transaksi Elektronik; b) Bahan hukum sekunder, meliputi literatur-literatur yang terkait dengan permasalahan yang dikaji yang berasal dari buku-buku, dokumen, makalah, jurnal, risalah, pendapat ahli hukum dari segi kepustakaan, dan artikel-artikel dari media cetak maupun yang elektronik yang terkait dengan permasalahan yang dikaji; dan c) Bahan hukum tersier, yaitu bahan yang memberi petunjuk atau penjelasan terhadap bahan hukum primer maupun sekunder, yaitu Kamus Besar Bahasa Indonesia (KBBI) dan Black's Law Dictionary. ${ }^{22}$

Analisis bahan hukum dilakukan dengan teknik analisis isi (content analysis). ${ }^{23}$ Analisis isi adalah teknik penelitian yang bertujuan untuk mencandra suatu pesan yang tersirat maupun tersurat. Dalam analisis isi, kandungan asas dan pasal-pasal relevan telah dipaparkan dan selanjutnya diinterpretasi ${ }^{24}$ dengan metode otentik. ${ }^{25}$ Teknik pengumpulan data dalam penelitian ini dilakukan melalui studi pustaka.

\section{PROBLEMATIKA PERLINDUNGAN HUKUM HAK CIPTA TERHADAP MOVIE ILLEGAL STREAMING DI INDONESIA}

22 Morris L, Sinopsis Penelitian ilmu hukum, 1st ed (Jakarta: Raja Grafindo Persada, 1995) at 71.

23 Valerine JL Kriekhoff, "Analisis Konten dalam Penelitian Hukum: Suatu Telaah Awal" in Kumpul Bahan Baca dalam Penataran Metod Penelit Huk (Cimanggis: Fakultas Hukum Universitas Indonesia, 1997) at 17.

24 Mertokusumo, Mengenal hukum (suatu pengantar) (Yogyakarta: Liberty, 2003) at 30 .

25 Yudha Bhakti Ardhiwisastra, Penafsiran dan Konstruksi Hukum, 1st ed (Bandung: P.T. Alumni, 2000) at 41. 
Dewasa ini, peran HKI yang juga dikenal dengan Intellectual Property Rights sangat penting bagi setiap aspek kehidupan manusia. Terlebih pada perkembangan dunia teknologi yang semakin canggih dan semakin meluasnya jaringan baik berskala nasional maupun global. HKI bukanlah sesuatu yang baru dalam perkembangan kehidupan manusia, Indonesia sendiri telah miliki peraturan perundangundangan yang mencakup HKI sejak masa penjajahan Belanda. Pada masa itu, berlaku HKI terdiri atas tiga bidang yaitu hak paten, hak cipta, dan merek dagang. Adapun HKI dalam peraturan perundangundangan pada masa itu yakni: 1) Autersweet 1912 (Undang-undang Hak Pengarang 1912; S.1912-600); 2) Reglement Industriale Eigendom Kolonien 1912; dan 3) Octrooiwet 1910 (Undang-undang Paten 1910; S.1910-33, yis S.1911-33,2.1922-54). ${ }^{26}$

Indonesia kemudian memiliki pengaturan HKI sebagai hukum positif untuk pertama kali pada tahun 1961 dalam Undang-Undang Merek tahun 1961, Undang-Undang Hak Cipta Nomor 6 Tahun 1982 yang diubah dengan Undang-Undang Nomor 7 Tahun 1987 yang kemudian dilakukan perubahan serta penyempurnaan pada Undang-Undang Nomor 12 Tahun 1997. Pengaturan berikutnya ialah Undang-Undang Nomor 19 Tahun 2002. Selanjutnya, pengaturan yang paling baru ialah UU No. 28 Tahun 2014 tentang Hak Cipta. Pengaturan tersebut dalam hal perubahan-perubahan tentunya tak terlepas dari peran Indonesia dalam kerjasama antara Indonesia dengan negara lainnya. Salah satunya melalui organisasi perdagangan dunia yang biasa dikenal dengan sebutan World Trade Organization (WTO) yang selanjutnya melahirkan General Agreement on Tariffs and Trade (GATT) sejak 1947 dan Agreement on trade Related Aspects of Intellectual Property Rights (TRIPs). Dalam organisasi

26 Adrian Sutedi, Hak Atas Kekayaan Intelektual (Jakarta: Sinar Grafika, 2019) at 40. 
tersebut, Indonesia meratifikasi persetujuan yang menyangkut aspek-aspek dagang berkaitan pada HKI dengan meratifikasi dalam bentuk undang-undang tentang hak cipta. TRIPs Agreement kemudian dimasukkan ke dalam hukum nasional yaitu UndangUndang Hak Cipta secara totalitas dimana pada TRIPs Agreement ini dilakukan tiga cara penerimaan yaitu: a) total atau menyeluruh; b) hanya hal-hal tertentu; dan c) memodifikasinya. ${ }^{27}$ Konsekuensi dari ratifikasi inilah yang mengakibatkan Indonesia harus mengikuti dan melaksanakan prinsip-prinsip yang tertuang dalam kesepakatan tersebut. $^{28}$

Menurut model hukum Anglo Saxon, terdapat istilah yang disebut dengan intellectual property rights (IPR). ${ }^{29}$ Dalam artiannya terdiri atas dua macam istilah dalam bidang hukum yaitu "Hak Milik Intelektual" (HMI) dan "Hak Atas Kekayaan Intelektual" (HAKI), namun dewasa ini istilah tersebut beralih menjadi "Kekayaan Intelektual (KI)." ${ }^{\prime 30}$ Namun, saat ini lebih umum digunakan akronim HKI, yang juga merupakan persamaan kata pada umumnya digunakan untuk IPR, dibandingkan HAKI (tanpa “Atas). ${ }^{31} \mathrm{Hal}$ ini juga termaktub dalam Surat Keputusan Menteri Hukum dan Peraturan Perundang-undangan RI Nomor M.03.PR.07.10 tahun 2000 dan Persetujuan Menteri Negara Pendayagunaan Aparatur Negara pasa surat nomor 24/M/PAN/1/2000. Pemakaian resmi istilah ini juga

27 Tri Setiady, "Harmonisasi Prinsip-Prinsip Trips Agreement Dalam Hak Kekayaan Intelektual Dengan Kepentingan Nasional" (2015) 8:4 FIAT JUSTISIAJurnal Ilmu Huk 595-613 at 600-603.

28 Ibid at 604.

29 Pablo Miguez, "Intellectual Property and The Forced Commodification of Knowledge" (2018) 2 Univ Rev Ciencias Soc Y Humanas 41-62 at 52-54.

30 Direktorat Jenderal Hak Kekayaan Intelektual, "Perkembangan Sistem Perlindungan Hak Kekayaan Intelektual di Indonesia" (2008) 5:3 Media HKI Bul Inf dan Keragaman at 11.

31 Ibid. 
189 I Mengoptimalkan Peran Badan Perfilman Indonesia: Analisis Aspek Hak Cipta terhadap Praktik Siaran Video Ilegal

didasari pada Keputusan Presiden RI Nomor 144 Tahun 1998 tanggal 15 September 1998 tentang perubahan nama Direktorat Jenderal Hak Cipta, Paten dan Merek yang berubah menjadi Ditjen HAKI yang kemudian diubah lagi menjadi Ditjen HKI berdasarkan Keputusan Presiden Nomor 177 Tahun 2000.32 Penggunaan istilah ini juga dipengaruhi oleh kaidah Bahasa Indonesia yang pada penulisan Istilah, tidak digunakan kata depan seperti "atas".33

Pengaturan HKI juga tak terlepas pada perjanjian TRIPs, dimana masyarakat yang tergabung dalam kesepakatan internasional ini wajib menyesuaikan peraturan yang berlaku di negaranya dengan ketentuan internasional. ${ }^{34}$

Kemajuan teknologi saat ini tidak dapat dipungkiri sangat berpengaruh pada kehidupan sosial manusia. Kemajuan teknologi akan berkaitan erat pada dunia modern dimana seluruh aspek kehidupan beralih menjadi serba dalam jaringan (daring). Hal ini kemudian akan menciptakan suatu kondisi dimana manusia akan bergantung pada teknologi komunikasi dan informasi karena kemudahannya dalam menjangkau pelosok dunia. Kemajuan ini akan bermanfaat bagi manusia apabila digunakan dengan sebaikbaiknya, contohnya akibat dari adanya kemajuan ini kita dimudahkan dalam melakukan transaksi lintas negara, kemudahan dalam mendapatkan barang dan jasa, kemudahan dalam mengakses dunia maya bahkan kemudahan dalam melakukan komunikasi jarak jauh. Namun, layaknya pedang bermata dunia, kemajuan ini juga berdampak negatif jika disalahgunakan. Penggunaan teknologi yang

32 Ibid.

33 Purba, "Pokok-Pokok Kebijakan Pembangunan Sistem HKI Nasional" (2001) 13 J Huk Bisnis.

34 Saidin, Aspek Hukum Kekayaan Intelektual (Intellectual Property Rights) (Jakarta: Raja Grafindo Persada, 2007) at 65. 
melenceng dari kebermanfaatannya cenderung akan menjadi tidak terkendali sehingga dapat menjadi bumerang bagi penggunanya. ${ }^{35}$ Tak ayal jika hal ini akan mengakibatkan adanya tindakan melawan hukum atau kriminalisasi dalam dunia maya, ${ }^{36}$ contohnya penipuan, transaksi jual-beli secara ilegal, pemerasan dalam bentuk digital, hingga pelanggaran hak cipta dengan memanfaatkan jaringan internet.

Menyoal pada pelanggaran hak cipta melalui internet, permasalahan ini bukanlah hal baru di Indonesia. Permasalahan ini selalu menjadi topik yang tak kunjung selesai terutama pada pembajakan karya dalam bentuk ilegal. Kasus pelanggaran hak cipta adalah kasus yang marak terjadi saat ini di mana hal ini akan menekan kreatifitas seseorang dalam berkarya. ${ }^{37}$ Indonesia sendiri memiliki pengaturan terkait pembajakan yang terkait dengan hak cipta yaitu dalam Undang-Undang Nomor 28 Tahun 2014 tentang Hak Cipta.

Pembajakan hak cipta yang marak terjadi saat ini ialah pembajakan film dimana maraknya streaming illegal melalui platform-platform yang tidak berbayar. Pembajakan film dapat dikatakan merupakan permasalahan yang paling menantang dalam industri media. ${ }^{38}$ Terlebih pada saat ini, pemberlakuan Pembatasan Sosial Berskala Besar (PSBB) menyebabkan masyarakat untuk melakukan pembatasan kegiatan di luar rumah. Penerapan PSBB merupakan

35 Etry Mike, "Perlindungan Hukum Hak Kekayaan Intelektual Terhadap Tindaka Pelanggaran Pembajakan Buku Elektronik Melalui Media Online" (2019) 2:2 Al Imarah J Pemerintah dan Polit Islam 135-144 at 138-140.

36 Ahmad M Ramli, Cyber law \& HAKI dalam sistem hukum Indonesia (Bandung: Refika Aditama, 2004) at 13.

37 Mirza Sheila Mamentu, Emma V T Senewe \& Jemmy Sondakh, "Penerapan Hukum Terhadap Pembajakan Film di Situs Internet Dalam Hubungannya Dengan Hak Cipta" (2021) 9:1 Lex Adm 5-13 at 8.

38 Arthur S De Vany \& W David Walls, "Estimating the effects of movie piracy on box-office revenue" (2007) 30:4 Rev Ind Organ 291-301, at 292. 
suatu fenomena di mana terjadi perubahan perilaku konsumen masyarakat. ${ }^{39}$ Masyarakat yang semula menonton film di televisi kini beralih menjadi streaming film di platform internet. Namun, tentunya kesempatan ini dimanfaatkan oleh oknum-oknum yang kemudian membajak film tersebut sehingga masyarakat dapat menonton secara gratis tanpa perlu mengeluarkan uang untuk menontonnya. ${ }^{40}$ Penutupan bioskop-bioskop akibat COVID-19 memperparah keadaan sehingga pendapatan industri perfilman tentunya akan semakin menurun. ${ }^{41}$ Dalam keadaan ini, kehadiran platform streaming film menjadi 'praktik perlawanan' terhadap film yang diputar di bioskop di saat filmnya sendiri menjadi sulit untuk diakses atau ditonton oleh sebagian besar masyarakat. Ditambah tidak semua kota di Indonesia memiliki bioskop di daerahnya. ${ }^{42}$ Sehingga, kehadiran internet saat ini dapat dengan mudah diakses oleh masyarakat guna sebagai langkah instan dalam menonton film.

Perkembangan ini melihat pada kebiasaan masyarakat yang biasanya pergi ke bioskop untuk menonton film. Jika dilihat pada perkembangan bioskop yang semakin lama semakin pesat diiringi dengan jumlah peminat film yang semakin banyak akibat faktor

39 Fahmi Ahmad Burhan, "Saingi IndoXXI, Aplikasi Vidio Diunduh 5 Juta Kali di Tengah Pandemi", (2020), online: Katadata $<$ https://katadata.co.id/desysetyowati/digital/5ebd51634f3f9/saingi-indoxxiaplikasi-vidio-diunduh-5-juta-kali-di-tengah-pandemi>.

40 Tangguh Okta Wibowo, "Fenomena Website Streaming Film di Era Media Baru: Godaan, Perselisihan, dan Kritik” (2018) 6:2 J Kaji Komun 191-203 at 194.

41 Ady Prawira Setyawan, "Jokowi Sambut Baik Usulan Penyelamatan Industri Film Indonesia”, (2021), Kompas.com <https://www.kompas.com/hype/read/2021/03/10/173002966/jokowi-sambutbaik-usulan-penyelamatan-industri-film-indonesia?page=all $>$.

42 Wibowo, supra note 41. 
populasi Indonesia, ${ }^{43}$ tidak dapat dipungkiri bahwa perkembangan bioskop sangat membantu industri perfilman di Indonesia. Namun, era digitalisasi serta diikuti dengan pandemi COVID-19 tentunya akan mengubah perilaku konsumen menjadi serba digital. Hal ini juga dianggap sebagai rangkaian dari pembajakan perangkat lunak (software) dan juga pembajakan musik secara digital. ${ }^{44}$ Teknologi memberikan ruang kebebasan bagi para penonton dan menghadirkan sebuah alternatif baru tanpa perlu pergi ke bioskop untuk menonton sebuah film. Perkembangan film di era digital ini menjadi hal vital yang kita sebagai penikmatnya perlu memahami posisi film dengan sifatnya yang cair (seamless), karena digitalisasi memudahkan konten untuk direproduksi dan didistribusikan. ${ }^{45}$ Selain itu, meskipun orang-orang sadar akan perbuatannya yang ilegal dan melanggar hukum, sebagian besar orang masih berpikir bahwa perbuatan tersebut dapat diterima secara moral. ${ }^{46}$

Distribusi yang semakin mudah ini kemudian menyebabkan seluruh konten film yang ada di situs-situs tersebut dapat diunduh dengan sangat mudah. Perlu dicatat bahwa situs-situs ini adalah situs yang terbuka, dimana seluruh elemen masyarakat dapat mengaksesnya. Dalam situs-situs tersebut pun dihadirkan banyak pilihan film dengan kategori yang variatif dan mencakup film baik produksi

43 Heri Suanto, "Tumbuh Pesat, Indonesia Pasar Potensial bagi Industri Film", (2019), online:

Katadata $<$ https://katadata.co.id/herisusanto/berita/5e9a551515805/tumbuh-pesatindonesia-pasar-potensial-bagi-industri-film>.

44 Johnny Nhan, Kendra Bowen \& Aaron Bartula, "A comparison of a public and private university of the effects of low-cost streaming services and income on movie piracy" (2020) 60 Technol Soc 1-8 at 3-5.

45 Wibowo, supra note 41.

46 Claudia Wilhelm, "Investigating Neutralization Strategies in Digital Piracy: The Role of Content Preferences and Social Norms" (2020) 64:2 J Broadcast Electron Media 320-340 at 333-335. 
nasional maupun produksi internasional. Kemudian, yang menjadi permasalahan ialah ketika pengguna situs tersebut mengunduh film, pengguna tidak perlu mendaftarkan dirinya sebagai bagian atau member dari situs tersebut. ${ }^{47}$ Sehingga hal ini menjadi sulit untuk dilakukan pelacakan bagi siapa saja yang masih mengakses situs streaming ilegal. ${ }^{48}$

Dengan banyaknya movie illegal streaming, dapat dipastikan bahwa hal ini sangat merugikan pihak pencipta, industri, maupun negara. Pembajakan itu sendiri dapat dikatakan merupakan sebuah perampokan. ${ }^{49}$ Dengan kata lain, hak milik orang lain diambil secara paksa dan tanpa consent dari si pencipta. Tidak hanya hasil jerih payahnya dalam pembuatan film itu yang diambil secara sepihak oleh pelaku pembajakan, namun juga royalty yang seharusnya diterima oleh pencipta, sehingga hal ini sama saja menutunkan pendapatan dari industri film tersebut. ${ }^{50} \mathrm{Hal}$ ini kemudian berkaitan dengan hak ekonomi atau pendapatan penjualan yang seharusnya menjadi miliknya. ${ }^{51}$

Banyak cara pembajakan dengan metode baru salah satunya melalui telegram. Mereka hanya perlu tahu nomor telepon calon korban sehingga dapat dicermati bahwa pembajakan yang dilakukan begitu mudah. Dikala aplikasi ini mengalami puncaknya dan digunakan

47 Denico Doly, "Penegakan Hukum terhadap Pembuat Situs Streaming Film Bajakan" (2009) 4:4 J IUS 1-6 at 3.

48 Hendrianto, supra note 12.

49 WJS Purwadarminta, Kamus umum bahasa Indonesia (Jakarta: Balai Pustaka, 1999).

50 Jordi McKenzie, "Graduated response policies to digital piracy: Do they increase box office revenues of movies?" (2017) 38:1 Inf Econ Policy 1-11 at 35.

51 M Smith, "I Want You Back: The Interplay Between Legal Availability and Movie Piracy" (2019) 26:1 Int J Econ Bus 199-216 at 203-207. 
oleh berbagai kalangan membuat para pelaku pembajakan menguntungkan hal ini dengan menyebarkan konten-konten illegal melalui aplikasi telegram. Terlebih dalam aplikasi ini memudahkan dalam mengakses film tanpa berbayar. fitur-fitur yang tersedia dalam Telegram disalahgunakan oleh oknum untuk penyebaran film secara ilegal. Salah satu fiturnya ialah Public channel, dimana fitur ini dibentuk oleh penggunanya untuk melakukan pengiriman pesan kepada banyak orang yang tergabung dalam kanal tersebut. Fitur inilah yang digunakan untuk menyebarluaskan film secara ilegal dan pengguna dapat mengaksesnya tanpa memerlukan biaya. ${ }^{52}$

Berdasarkan media The Outline yang mengutip dari Business Insider Singapura, sejumlah kelompok kanal ini bahkan sengaja mengirimkan konten bajakan melalui kanal mereka, dan kebanyakan konten tersebut dicuri dari Netflix dan Spotify. Terlebih Telegram merupakan media yang tidak begitu tegas dalam menghapus grup atau kanal yang berperan dalam pembajakan konten. ${ }^{53}$ Pendiri public channel tersebut juga nantinya akan mendapatkan keuntungan berupa panambahan pengikut kanal dan tawaran paid promote oleh online shop. Paid promote ini merupakan jasa dimana seseorang atau lebih yang memiliki engagement yang tinggi dibayar untuk mempromosikan barang atau jasa online shop di media sosial. ${ }^{54} \mathrm{Hal}$ ini jelas melanggar pada Pasal 1 angka 1 Undang-Undang Nomor 28 tahun 2014 terkait hak ekslusif milik pencipta dalam mendapatkan

52 Kemala Megahayati, Muhamad Amirulloh \& Helitha Novianty Muchtar, "Perlindungan Hukum Sinematografi Terhadap Pengaksesan Tanpa Hak Oleh Pengguna Aplikasi Telegram Berdasarkan Undang-Undang Hak Cipta dan Undang-Undang Informasi dan Transaksi Elektronik di Indonesia" (2021) 5:1 Ajudikasi J Ilmu Huk 1-16 at 1-2.

53 Astuti, R. Marpaung, D, S, supra note 17.

54 Nanda Putri Arifah \& Carolina Novi Mustikarini, "Paid Promote Sebagai Media Promosi Produk Delicy Dalam Meningkatkan Konsumen Potensial" (2016) 1:3 J Performa 307-313 at 311. 
keuntungan baik keuntungan ekonomis maupun keuntungan lainnya.

Berdasarkan pernyataan dari Ketua Lembaga Riset Keamanan Siber dan Komunikasi CISSReC, Pratama Persadha, menonton ataupun mengunduh film secara ilegal melalui situs film yang juga ilegal dapat membahayakan perangkat atau gadget pengguna. ${ }^{55}$ Menurutnya, situs-situs film ilegal berpotensi menyusupkan malware ke perangkat pengguna. Dengan kata lain bahwa adanya pembajakan movie illegal streaming tidak hanya merugikan pencipta, negara tapi juga merugikan para penonton itu sendiri, mereka mendapatkan keuntungan dengan menonton film dengan mudah. Namun, mereka secara tidak sadar dapat membahayakan perangkat yang mereka gunakan untuk menonton movie illegal streaming tersebut. Maka kita harus selektif terhadap situs-situs yang tidak resmi, jangan hanya karena kenikmatan sesaat untuk menonton film dengan mudah tapi perangkat dan data diri kita menjadi terampas.

Di sisi lain, jika menilik pada tingkah laku pengguna dalam melakukan movie illegal streaming, pengguna akan merasa senang dan tertantang untuk terlibat dalam aktivitas ilegal karena tidak ada yang mencoba untuk menghentikan perbuatannya serta menangkapnya pada saat mereka melakukan perbuatan tersebut meskipun hal itu merupakan tindakan kriminal. Pengguna juga akan merasakan ketakutan serta rasa bersalah apabila pihak berwenang memberikan sanksi bagi para pelanggarnya. ${ }^{56}$

55 CNN Indonesia, "Bahaya Nonton Film di Situs Bajakan seperti IndoXXI", (2019), online: <https://www.cnnindonesia.com/teknologi/20191220073003185-458560/bahaya-nonton-film-di-situs-bajakan-seperti-indoxxi>.

56 I Phau, "Investigating the Factors Influencing Digital Movie Piracy" (2016) 22:5 J Promot Manag 637-664 at 640-642. 
Oleh karena itu, penting akan adanya suatu perlindungan hukum terhadap problematika movie streaming illegal. Pengembangan konsep ini dapat dikatakan sebagai upaya apresiasi dalam menghormati dan menghargai jerih payah orang lain. ${ }^{57}$

\section{OPTIMALISASI LEMBAGA PERFILMAN SEBAGAI UPAYA PERLINDUNGAN HAK CIPTA TERHADAP MOVIE ILLEGAL STREAMING DI INDONESIA}

Penanganan Film merupakan sebuah karya yang sampai saat ini masih popular dan berkembang pesat. Film adalah karya yang dapat dinikmati oleh masyarakat sehingga masuk dalam kategori karya cipta, dimuat dalam pasal 58 ayat (1) UU Hak Cipta. Berkaitan dengan kenikmatan dan keuntungan yang diperoleh pencipta bisa dinikmati seluruhnya tanpa adanya penyeludupan oleh pihak lain. Jika dilihat dan dicermati dari isi pasal perpasal diundang-undang hak cipta sudah mengakomodir seluruh hak dari karya yang diciptakan oleh pencipta. Namun, jika awasi dan dirasakan secara realita perlu adanya eksekusi lanjutan dan dukungan dari berbagai pihak demi terlaksananya undang-undang yang telah disusun. Maka pengaturan yang telah dibuat tidak hanya untuk menakut-nakuti tetapi bentuk nyata.

Konsep optimalisasi lembaga perfilman ini, memberikan upaya dalam pelaksanaan pengoptimalan melalui lembaga-lembaga yang terkait. Pertama Kominfo, tugas dan fungsi utama berkaitan dengan cara perumusan kebijakan nasional, kemudian pelaksanaan

57 Bambang Kesowo, Implementasi Undang-Undang Hak Cipta (2000). 
kebijakan tersebut hingga teknis pelaksanaan bidang komunikasi dan Informatika yang tersedia di Indonesia. ${ }^{58}$

Kedua Direktorat Jenderal HKI (DJKI) adalah sebuah unit organisasi Eselon I di lingkungan Kementerian Hukum dan Hak Asasi Manusia Republik Indonesia. ${ }^{59}$ Bertugas sebagai regulator, administrator dan penegak huku dalam perlindungan HKI, sebagai peran aktif kepada masyarakat dalam melindungi hak cipta di Indonesia. Dalam hal publikasi, DJKI memberikan sosialisasi tata cara publikasi kepada masyarakat. Informasi dapat berupa berita guna mendapatkan kepercayaan masyarakat kepada DJKI dan memberikan edukasi pemberian informasi yang layak untuk publikasi di masyarakat. DJKI harus membangun kesadaran hak cipta kepada masyarakat dengan menginformasikan, mengedukasi, menyebarkan, dan meningkatkan citra yang baik di masyarakat.

Ketiga organisasi Komisi Penyiaran Indonesia (KPI) sebagai organisasi ranah publik yang independen dan bebas dari kepentingan apapun, KPI bertugas dalam memeberikan ketegasan pengelolaan sistem penyiaran. ${ }^{60} \mathrm{KPI}$ sebagai organisasi penyiaran memiliki tugas yang berbeda dari organisasi perfilman lain, berkaitan dengan segala bentuk penyiaran film. Namun secara praktik, seringkali KPI dikaitkan dengan Lembaga Sensor Film (LSF) di Indonesia. Beda dari kedua lembaga tersebut yaitu, KPI adalah lembaga negara yang bersifat independen yang ada di pusat dan di

58 Kominfogoid, "Kementerian Komunikasi dan Informatika Tentang Tugas Kominfo", $\quad$ online: <https://www.kominfo.go.id/tugas-danfungsi\#: :text=Tugas \%26 Fungsi Kementerian Komunikasi dan,Presiden dalam menyelenggarakan pemerintahan negara.>.

59 Avissa Yufen Fabrianne \& Yugih Setyanto, "Upaya Humas Direktorat Jenderal Kekayaan Intelektual dalam Membangun Kesadaran Hak Cipta" (2019) 2:2 Prologia 257-262 at 257-258.

60 “Undang-undang Nomor 32 Tahun 2002 tentang Penyiaran". 
daerah, dan Lembaga Sensor Film adalah Sementara itu, (LSF) adalah lembaga yang bertugas menetapkan status edar film-film di Indonesia. ${ }^{61} \mathrm{KPI}$ termasuk salah satu lembaga pengawas masyarakat yang menunjang program sekaligus kegiatan dari hal terknis hingga administrasi dalam penyiaran perfilam di Indonesia. Jika dihubungkan dengan teori tentang kelembagaan negara, KPI termasuk lembaga negara penunjang yang menjalankan fungsi eksekutif (pelaksana administratif). ${ }^{62}$

Keempat organisasi Video Coalition of Indonesia (VCI) dalam penerapannya akan bekerjasama dengan Kementerian Komunikasi dan Informatika (Kemenkominfo) sebagai bentuk bantuan mengidentifikasi situs pembajakan film dan aplikasi ilegal. ${ }^{63}$ Baik Kementerian dan organisasi yang tergabung dalam konsep ini akan saling bekerjasama. Tugas dari masing-masing organisasi tetap sesuai dengan kebijakan tiap organisasi, namun dalam hal ini Kominfo akan mengikutsertakan para organisasi lain untuk bersamasama mengantisipasi adanya domain streaming illegal yang beredar dengan pembagian sesuai tugas sesuai tupoksi masing-masing. Dalam pelaksanaan antara organisasi satu dengan yang lain saling bekerjasama dengan pihak Kementerian Kominfo sebagai kordinator organisasi yang ada.

61 Suyadi Asip, “Kedudukan Dan Kewenangan Komisi Penyiaran Indonesia Dengan Lembaga Sensor Film Mengenai Kepastian Hukum Bidang Perfilman" (2019) 2:1 J Ilmu Huk 449-463 at 450-452.

62 Ibid.

63 Muhammad Aulia, "Vidio Coalition Of Indonesia Serukan Tindakan Tegas Lawan Pembajakan", (2020), online: iNews.id $<$ https://www.inews.id/finance/makro/video-coalition-of-indonesia-serukantindakan-tegas-lawan-pembajakan>. 


\section{Pemasyarakatan}

Permasalahan dalam undang - undang tentang Penyiaran memiliki banyak polemik walaupun telah berlangsung selama 10 tahun diundangkan. Ada perubahan yang membaha dampak negative dalam UU penyiaran, pertama yaitu dibentuknya badan regulator penyiaran yaitu KPI, kedua, yaitu sistem siaran berjaringan, perubahan ketiga, yaitu dijaminnya LPK, keempat, LPP, dan kelima pembatasan LPS. ${ }^{64}$ Penerapan UU tersebut banyak menuai perdebatan hingga adanya pengajual judicial review kepihak MK. Permasalahan-permasalahan yang dihadapi oleh UU penyiaran merupakan permasalahan krusial bagi lembaga penyiaran, Pemerintah maupun KPI. ${ }^{65}$ Dari segi sanksi administrasi menurut KPI kurang memiliki dampak yang signifikan pada masyarakat, menimbulkan peluang konten yang tidak layak tampil bisa lolos tampil dilayar kaca atau situs streaming dengan mudah.

Upaya pemasyarakatan akan ada pengawasan sebelum konten diluncurkan kepada masyarakat umum. Hal ini bertujuan mengurangi pelanggaran-pelanggaran terhadap Undang-Undang Penyiaran, kemudian akan selalu dikoordinasikan dengan Kominfo sebagai kementerian komunikasi dan informatika. Konten yang akan dirilis kepada masyarakat terintegrasi dengan baik oleh pihak pemerintah.

Situs yang akan rilis akan dilakukan beberapa tahap cek in untuk memeriksa standart yang sesuai dalam peraturan yang berlaku tentang publikasi perfilman. Kemudian bagi konten yang telah rilis akan dilakukan pengawasan dalam memberikan tayangan sesuai

64 Denico Doly, “Urgensi Perubahan Undang-Undang Nomor 32 Tahun 2002 tentang Penyiaran" (2013) 4:2 Negara Huk 215-230 at 215-216.

65 Ibid. 
rekam jejak publikasi serta akun-akun yang mengakses konten tersebut berada. Pewangan ini demi mewujudkan kelayakan kualitas publikasi bagi masyarakat dalam menonton konten-konten yang telah medapatkan izin legal dengan kualitas yang baik. Dampak dengan adanya pemasyarakatan ini sebagai proses dimana komunikasi jaringan dan layanan diintegrasikan menjadi satu sheingga dapat memberikan layanan berupa audia, visual dan trasmisi data yang serupa. ${ }^{66}$

Pengawasan dalam hal ini sebagai perwujudan upaya dengan pencegahan preventif, disebut juga upaya mencegah terjadinya pelanggaran HKI. Pencegahan preventif dimaknai sebagai perlindungan HAM manusia satu dengan yang lainnya sebelum hal tersebut terjadi dan perlindungan ini ditujukan kepada masyarakat karena hukum telah memberikan hak-hak khusus yang bisa dinikmati oleh masyarakat. Bisa disebut juga sebagai upaya dalam rangka kewajiban memberikan perlindungan dari aparat penegak hukum kepada masyarakat dalam memberikan rasa aman diberbagai kondisi. ${ }^{67}$

KPI sebagai regulator penyelenggaraan penyiaran di Indonesia mengusahakan dari segi konten sebelum ditonton oleh masyarakat luas. Selain konten yang diawasi KPI juga menghimbau masyarakat yang telah menonton konten tersebut sangat dilarang keras untuk menyebarkan film tanpa adanya seizin dari pihak pencipta atau lembaga yang memberikan izin tersebut. Memberikan himbauan kepada masyarakat untuk tidak menikmati sebuah karya film secara illegal dengan cara melakukan sosialisasi pada seluruh platform

${ }^{66}$ Djulaeka \& Rhido Jusmadi, "Konvergensi Telematika, Arah Kebijakan Dan Pengaturannya Dalam Tata Hukum Indonesia" (2013) 2:3 Yust J Huk 46-60 at 50-52.

67 Satjipto Rahardjo, Ilmu Hukum (Bandung: PT. Citra Aditya, 2014) at 88. 
yang dimiliki oleh organisasi KPI dan juga Kominfo. Pelanggaran ini jelas termuat dalam pasal 3 huruf a Undang-Undang Nomor 28 tahun 2014 terkait menikmati hak eksklusif orang lain. Masyarakat lain tidak bisa mengklaim hak orang lain selain pencipta atau pembuat karya itu sediri, karena setiap hak hanya diberikan kepada orang yang berhak memilikinya dari karya yang telah dibuat dan bagi karya yang dilindungi dalam hak cipta.

\section{Perlindungan}

Setiap orang yang menghasilkan karya intelektual tentunya layak mendapatkan perlindungan hukum. Hal ini sejalan dengan Pasal 27 The Universal Declaration of Human Rights dimana dalam pasal tersebut dapat diartikan bahwa: 1) Hak partisipasi setiap orang dalam kehidupan berbudaya suatu masyarakat, dalam hal menikmati dan/atau membagikan kemajuan ilmu serta manfaatnya; 2) Hak perlindungan moral dan materiil bagi setiap orang dari hasil karya yang telah diciptakan olehnya. Berlakunya perlindungan secara universal ini secara mutlak bagi siapapun subjek hukumnya. ${ }^{68}$ Sesuai pasal 7 TRIPS (Tread Related Aspect of Intellectual Property Right) menjabarkan tujuan dari perlindungan dan penegakan hak atas kekayaan intelektual adalah perlindungan dan penegakan hukum HKI memberikan tujuan dalam upaya dukungan adanya inovasi baru bagi setiap penciptanya, pengalihan dan penyebaran teknologi memberikan dampak positif terhadap penghasilan dan pemahaman teknologi baru bagi setiap penciptanya untuk selalu menemukan ideide baru, dan menciptakan kesejahteraan sosial dan ekonomi serta

68 R Soeroso, Pengantar ilmu hukum, 1st ed (jakarta: Sinar Grafika, 2017) at 58. 
keseimbangan antara hak dan kewajiban setiap manusia. ${ }^{69}$ Maka penting sekali adanya perlindungan guna menegakkan hak atas kekayaan intelektual baik individu maupun kelompok.

Perlindungan hukum dalam hal ini dilakukan secara represif, yaitu perlindungan akhir berupa sanksi seperti denda, penjara, dan hukuman tambahan yang diberikan apabila sudah terjadi sengketa atau telah dilakukan suatu pelanggaran. ${ }^{70}$ Menindaklanjuti perlunya perlindungan secara hukum maka pemerintah mengeluarkan pengaturan, guna perlindungan lebih lanjut dalam Undang-Undang Nomor 28 Tahun 2014 tentang Hak Cipta mengatur tentang pencegahan, pelanggaran hak cipta dan hak lain yang terkait melalui sarana teknologi yang mendukung upaya pencegahan pelanggaran hak cipta sebuah karya. Pada pasal 56-58 pemerintah memiliki sebuah solosi dalam pemblokiran pada website yang teridentifikasi melakukan pelanggaran hak cipta tersebut. Wujud nyata pada pasal tersebut memberikan wewenang kepada pemerintah untuk melakukan pemantauan pada tindakan penyebaran pelanggaran hak cipta secara, sekaligus menggandeng beberapa pihak untuk diajak bekerjasama untuk mengawasi berbagai media apapun yang digunakan untuk tindakan perekaman pada suatau ciptaan atau produk yang dipertujunkan secara tanpa izin.

Aturan hak cipta menganut prinsip deklaratif memberikan makna bahwa setiap orang pertama kali yang memberitahukan secara umum kepada halayak ramai dan diakui oleh pihak lain, meskipun tidak tercatat dalam perlindungan HKI namun pencipta dapat

69 Ayup Suran Ningsih \& Balqis Hediyati Maharani, "Penegakan Hukum Hak Cipta Terhadap Pembajakan Film Secara Daring" (2019) 2:1 J Meta Yuridis 1332 at 22.

70 Muchsin, Perlindungan dan Kepastian Hukum bagi Investor Indonesia (Surakarta: Fakultas Hukum Universitas Sebelas Maret, 2003) at 51. 
memanfaatkan karya tersebut untuk kepentingan ekonomi. ${ }^{71}$ Namun jika hanya dengan prinsip tersebut secara faktanya dirasa kurang memiliki kekuatan hukum bagi pencipta terkait pengakuan ciptaan yang diatur dalam pasal 64 UU Hak Cipta. Maka ditambah dengan pengaturan tambahan untuk terkait provider seluruh Indonesia.

Terdapat provider secara wireless diwujudkan pada Peraturan Menteri Komunikasi dan Informatika Republik Indonesia Nomor 2 Tahun 2013 Tentang Penyedia Jasa Akses Internet Tanpa Kabel (Wireless) Pada Program Kewajiban Layanan Universal. Dimana seluruh provider digital yang ada di Indonesia harus mengikuti kebijakan yang dibuat oleh Kominfo. Jika terdeteksi ada yang tidak sesuai dengan kebijakan tersebut, maka dalam waktu beberapa hari domain tersebut akan mendapat notifikasi pada sistem Kominfo. Notifikasi tersebut menandakan harus ada pengecekan lanjutan untuk provider tersebut secara tegas. Dalam beberapa hari kedepan situs yang menggunakan provider tidak memenuhi ketentuan tersebut akan mengalami ganggu pada kelancaran pemutaran konten dan resolusi tampilan. Ketika ada peringatan dan dilakukan pengecekan oleh pihak Kominfo terdapat pelanggaran maka akan dit take down secara manual dan berlaku tanpa ada batas waktu. ${ }^{72}$

\section{Pengawasan}

Beberapa hal dari pengawasan lebih rentan terhadapa pembajakan konten illegal karena seringkali berula tersebar dari asal pertama film tersebut ditayangkan, seperti bioskop atau situs nonton film secara

71 Riko Sulung Raharjo, M Khoidin \& Ermanto Fahamsyah, "Perlindungan Hukum terhadap Pencipta atas Pencatatan Suatu Ciptaan yang Sama" (2018) 5:3 Lentera Huk 465-482 at 470.

72 Kominfogoid, "Sertifikasi Alat \& Perangkat Telekomunikasi", (2013), online: $<$ https://www.kominfo.go.id/content/detail/3346/sertifikasi-alat-perangkattelekomunikasi/0/layanan_kominfo>. 
online. Lemahnya pengawasan yang dilakukan oleh pihak penyiar dalam proses penayangan film di bisokop - bisokop. ${ }^{73}$ Michael Strangelove memberikan hasil diskusi terhadap pembajakan film dan televisi dalam 2 bentuk: pertama download dan kedua streaming. Sistem yang digunakan dalam pembajakan tersebut yaitu P2P seperti BitTorrent. ${ }^{74}$ Jika dibandingkan antara download dengan streaming jelas lebih banyak peminat streaming karena rentan waktu untuk menonton film tersebut lebih dahulu adalah streaming dan download harus menunggu beberapa sat terlebih dahulu untuk dapat menonton film tersebut.

Hadirnya kasus yang sangat lazim, maka dari segi pengawasan akan dibantu oleh Video Coalition of Indonesia (VCI) selaku organisasi yang memantau pergerakan domain illegal. Ditahun 2020 Kominfo bekerja sama dengan (VCI), telah memblokir lebih dari 2.300 situs streaming pembajakan dan aplikasi ISD situs pembajakan diblokir setiap 10 hari. ${ }^{75} \mathrm{Hal}$ ini menunjukkan suatu prestasi yang baik bagi VCI maka dirasa tepat jika Kominfo bekerjasama dengan VCI pada pengawasan layanan streaming illegal. Untuk mendukung kinerja VCI, Keminfo juga membuka sebuah website pelaporan untuk mengurangi objek pengguna (masyarakat)/penikmat domain pembajakan tersebut.

Website ini bernama Psyper dengan berbagai fitur pelaporan. Website ini diharapkan dalam memaksimalkan monitoring steakholder terkait dalam pengawasan movie illegal, selain itu juga memudahkan

73 Mamentu, Senewe \& Sondakh, supra note 38.

74 Irham Nur Anshari, "Sirkulasi Film dan Program Televisi di Era Digital: Studi Kasus Praktik Download dan Streaming melalui Situs Bajakan" (2019) 10:2 Komuniti J Komun dan Teknol Inf 88-102 at 88-90.

75 Kominfogoid, “Dalam 10 Bulan, Penonton Streaming Bajakan Menurun 55 Persen", (2020), online: <https://kominfo.go.id/content/detail/27915/dalam-10bulan-penonton-streaming-bajakan-menurun-55-persen/0/sorotan_media>. 
masyarakat dari berbagai kalangan dalam melaporkan kejadian yang dapat merugikan berbagai pihak. Website ini juga sebagai perlindungan dan sarana pengaduan secara secra online pada karya yang telah diproduksi agar tidak terjadi pembajakan dan merugikan pihak siapapun. Laporan yang diajukan bisa dari masyarakat selaku penonton, para pihak pemberi izin tayang atau para pembuat film itu sendiri. Dari segi fitur sendiri pada tampilan awal website pengunjung akan disuguhkan dengan tampilan seperti berikut. Ketika masyarakat menombol fitur beranda maka akan disuguhkan dengan berbagai data informasi terkait movie streaming iilegal di Indonesia, baik berupa pengaturan yang berlaku untuk menjerat para penyebar dan penikmat akses tersebut, informasi kasus yang ada dibeberapa negara.

Kedua pada fitur bantuan masyarakat akan dipandu mengenai website tersebut apabila terdapat gangguan atau problem saat akan login pengisian. Ketiga adanya fitur FAQ yang berisikan pertanyaan yang sering diajukan kepada pihak Kominfo terkait website tersebut sehingga masyarakat dapat memahami jika ada pertanyaan yang serupa dengan yang ditampilkan dalam fitur FAQ. Keempat fitur Kontak berisikan kontak dari pusat Kominfo baik media sosial kontak person salah satu pemegang kepercayaan Kominfo maupun berbegai situs Kominfo yang dapat dihubungi oleh masyarat. Kelima Tutorial masyarakat sebagai pengunjung akan diarahkan pada panduan untuk pengisian website tersebut secara runtut.

Website tersebut juga dilengkapi ucapan terimakasih atas kunjungan masyarakat yang menandakan bahwa masyarakat mendukung dan memberikan perhatian lebih terkait movie illegal streaming di Indonesia. Latar dari website psyper dapat diubah dengan beberapa tampilan yang tersedia pada menu informasi pada pojok kiri atas. 
Untuk melakukan pelaporan, masyarakat bisa secara langsung memilih fitur lapor yang kemudian akan masuk pada halaman berikutnya untuk mengisi pelaporan pada kasus movie illegall streaming.

\section{Gambar 1. Desain Website Pelaporan Tampilan Awal}

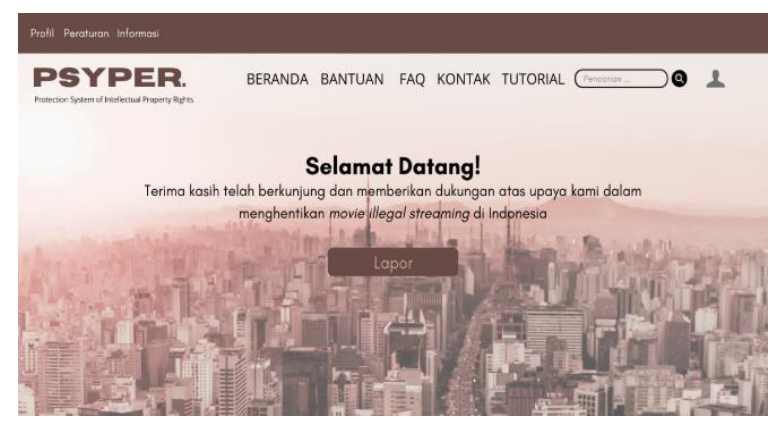

\section{Sumber: Kreasi Penulis}

Ketika pelapor telah masuk dari tampilan awal akan berganti pada tampilan inti. Untuk melapor mereka mengimput data diri berupa Nama lengkap pelapor sebagai bentuk identifikasi kecocokan dengan data penduduk Indonesia, Nomor Induk KTP (NIK) menunjukkan bahwa warga asli Indonesia yang melapor dan bukan akun palsu, link domain movie streaming illegal yang hendak dilaporkan, keluhan apa yang mereka rasakan sehingga berniat untuk melaporkan link tersebut atau bisa juga diisi dengan alasan melakukan pelaporan pada link movie streaming illegal itu dan diakhir pelapor diminta mengimput nomor telfon mereka guna dihubungi lebih lanjut oleh pihak Kominfo. Setelah data diisi sesuai yang ada, klik tombol lapor untuk submit pelaporan tersebut. Seluruh akun yang terekam akan menjadi rekap data oleh pusat dan jika ditemui adanya ketidak sesuaian pada data yang di input maka dapat dikenai pasal pemalsuan data diri pasal 64 ayat 1 Kitab Undang-Undang Hukum Pidana (KUHP).

\section{Gambar 2. Desain Website Pelaporan Tampilan Inti}




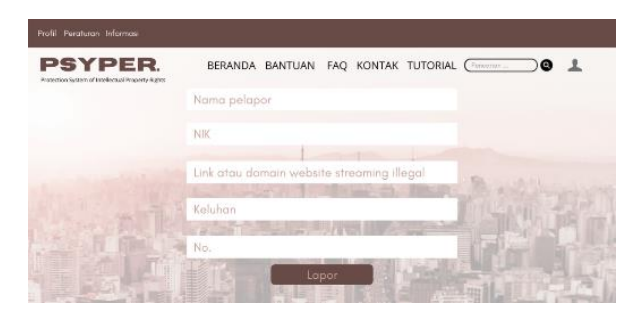

\section{Sumber: Kreasi Penulis}

Setelah seluruh data terinput maka tampilan akan berganti pada tampilan penutup dengan adanya ucapan terimakasih dan adanya apresiasi yang akan diberikan oleh pihak Kominfo ketika data telah direkam dan direkap seluruhnya bahwa data telah valid dengan keasliannya. Pada samping kanan dilengkapi pula dengan grafik balok yang menunjukkan link pelaporan yang memiliki jumlah pelapor terbanyak dalam kurun waktu yang ada. Data tersebut akan selalu di upgrade sesuai dengan jumlah pengunjung yang melapor dan submit laporan tersebut. Link domain yang dimunculkan dalam grafik balok bukan merupakan link lengkap agar menjaga kerahasiaan link tersebut.

\section{Gambar 3. Desain Website Pelaporan}

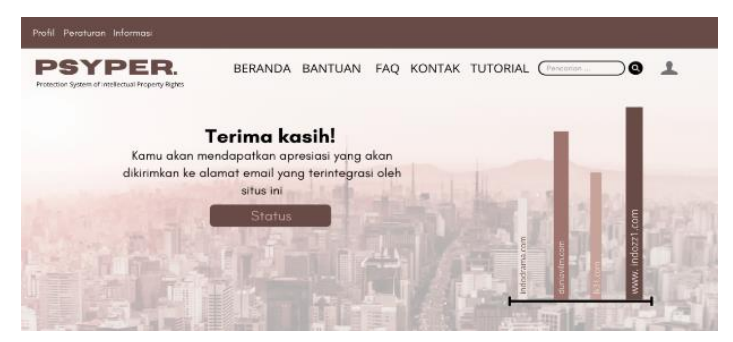

\section{Sumber: Kreasi Penulis}

Sistem pelaporan sendiri nantinya akan dikoordinasikan langsung oleh pihak Keminfo, tiap hasil dari website

ini akan ditampilkan dalam bentuk grafik balok sebagai upaya transparansi domain yang dilaporkan kepada seluruh masyarakat. Kemudian masyarakat yang sudah melaporkan adanya domain streaming illegal secara otomatis akun mereka akan terblokir pada 
domain pembajakan tersebut dan dihubungi langsung oleh pihak Kominfo untuk mendapatkan imbalan balik. Imbalan balik dari Kominfo ini sebagai bentuk ucapan terimakasih kepada masyarakat yang mau mendukung pemerintah dalam memberantas layanan streaming illegal. Pelaporan ini akan terus dicatat hingga memenuhi ambang batas pelaporan. jika banyaknya yang melapor dan sudah memenuhi ambang batas maka domain akan ditake down secara otomatis dari sistem dengan jangka waktu permanan, baik domain bajakan dan akun real pelaku pembajakan tersebut juga terkena imbasnya.

\section{KESIMPULAN}

Permasalahan mengenai maraknya pembajakan yang dilakukan oleh orang-orang yang tidak mendapatkan izin secara legal dapat memanfaatkan popularitas film dengan melakukan pelanggaran hak cipta untuk mencari keuntungan pribadi. Cara yang digunakan para pembajak konten secara illegal menggunakan internet yang kemudian menyebarkan situs penyedia layanan film streaming secara gratis. Cara ini merupakan suatu tindakan yang melanggar hak cipta terhadap movie illegal streaming. Trafik tingginya masyarakat melakukan movie illegal streaming di tengah pandemi COVID-19 yang dapat merugikan para pelaku industri film dan pemerintah. Banyak upaya yang telah dilakukan oleh pemerintah dalam memberantas kejahatan yang dilakukan oleh oknum yang tidak bertanggung jawab. Namun, sampai saat ini belum maksimal.

Maka, dari itu penulis menggagas konsep yang berjudul Optimalisasi Lembaga Perfilman sebagai Upaya Perlindungan Hak Cipta Terhadap Movie Illegal Streaming di Indonesia. Sebuah konsep menggunakan tiga komponen yaitu pemasyarakatan, pengawasan, 
dan dan perlindungan terhadap hak cipta tehdap movie illegal streaming di Indonesia. Harapannya konsep ini dapat memaksimalkan peran stekeholder dengan meminimalisir terjadinya movie streaming illegal dan sekaligus memberikan perlindungan pada industri film dalam karya cipta film yang dibuatnya.

\section{DAFTAR PUSTAKA}

Budi Santoso, HKI Hak Kekayaan Intelektual, 2d ed (Semarang: Pustaka Magister, 2011).

Ibrahim, Johnny, Teori dan metode penelitian hukum normatif (Malang: Bayumedia Publishing, 2005).

Isnaini, Yusran, Buku pintar HAKI tanya jawab seputar Hak Kekayaan Intelektual (Bogor: Ghalia Indonesia, 2010).

L, Morris, Sinopsis Penelitian ilmu hukum, 1st ed (Jakarta: Raja Grafindo Persada, 1995).

Marzuki, Peter Mahmud, Penelitian Hukum (Jakarta: Kencana, 2007).

Mertokusumo, Mengenal hukum (suatu pengantar) (Yogyakarta: Liberty, 2003).

Muchsin, Perlindungan dan Kepastian Hukum bagi Investor Indonesia

(Surakarta: Fakultas Hukum Universitas Sebelas Maret, 2003).

Purwadarminta, WJS, Kamus umum bahasa Indonesia (Jakarta: Balai Pustaka, 1999).

Rahardjo, Satjipto, Ilmu Hukum (Bandung: PT. Citra Aditya, 2014).

Ramli, Ahmad M, Cyber law \& HAKI dalam sistem hukum Indonesia (Bandung: Refika Aditama, 2004).

Saidin, Aspek Hukum Kekayaan Intelektual (Intellectual Property Rights) (Jakarta: Raja Grafindo Persada, 2007).

Soerjono Soekanto, Sri Mamudji, Penelitian hukum normatif: suatu tinjauan singkat, 17th ed (Jakarta: Rajawali Pers, 2015).

Soeroso, R, Pengantar ilmu hukum, 1st ed (jakarta: Sinar Grafika, 2017). Supramono, Gatot, Hak cipta dan aspek-aspek hukumnya (Jakarta: Rineka Cipta, 2010). 
Sutedi, Adrian, Hak Atas Kekayaan Intelektual (Jakarta: Sinar Grafika, 2019).

Yudha Bhakti Ardhiwisastra, Penafsiran dan Konstruksi Hukum, 1st ed (Bandung: P.T. Alumni, 2000).

Anshari, Irham Nur, "Sirkulasi Film dan Program Televisi di Era Digital: Studi Kasus Praktik Download dan Streaming melalui Situs Bajakan" (2019) 10:2 Komuniti J Komun dan Teknol Inf 88-102.

Arifah, Nanda Putri \& Carolina Novi Mustikarini, "Paid Promote Sebagai Media Promosi Produk Delicy Dalam Meningkatkan Konsumen Potensial" (2016) 1:3 J Performa 307-313, online: $<$ https://journal.uc.ac.id/index.php/performa/article/view/173>

Asip, Suyadi, "Kedudukan Dan Kewenangan Komisi Penyiaran Indonesia Dengan Lembaga Sensor Film Mengenai Kepastian Hukum Bidang Perfilman" (2019) 2:1 J Ilmu Huk 449-463.

Astuti, R Marpaung, D, S, H, "Perlindungan Hukum Terhadap Pemegang Hak Cipta Terkait Pembajakan Sinematografi di Aplikasi Telegram" (2021) 27:7 J Ilm Ilmu Huk 992-1006.

Direktorat Jenderal Hak Kekayaan Intelektual, "Perkembangan Sistem Perlindungan Hak Kekayaan Intelektual di Indonesia" (2008) 5:3 Media HKI Bul Inf dan Keragaman 11.

Djulaeka \& Rhido Jusmadi, "Konvergensi Telematika, Arah Kebijakan Dan Pengaturannya Dalam Tata Hukum Indonesia" (2013) 2:3 Yust J Huk 46-60.

Doly, Denico, "Penegakan hukum terhadap pembuat situs streaming film bajakan" (2009) 4:4 J IUS 1-6, online: $<$ https://sdip.dpr.go.id/search/detail/category/Info Singkat/id/1021>.

- - - , “Urgensi Perubahan Undang-Undang Nomor 32 Tahun 2002 tentang Penyiaran" (2013) 4:2 Negara Huk 215-230.

Fabrianne, Avissa Yufen \& Yugih Setyanto, “Upaya Humas Direktorat Jenderal Kekayaan Intelektual dalam Membangun Kesadaran Hak Cipta" (2019) 2:2 Prologia 257-262.

Hendrianto, "Perlindungan Hukum Bagi Pemegang Hak Cipta Film 
Dari Kegiatan Streaming dan Download Pada Website Illegal" (2019) 6:1 JOM Fak Huk Univ Riau 1-15, online: $<$ https://jom.unri.ac.id/index.php/JOMFHUKUM/article/view/ 24622/23846>.

Kriekhoff, Valerine JL, "Analisis Konten dalam Penelitian Hukum: Suatu Telaah Awal" in Kumpul Bahan Baca dalam Penataran Metod Penelit Huk (Cimanggis: Fakultas Hukum Universitas Indonesia, 1997).

Mamentu, Mirza Sheila, Emma V T Senewe \& Jemmy Sondakh, "Penerapan Hukum Terhadap Pembajakan Film di Situs Internet Dalam Hubungannya Dengan Hak Cipta" (2021) 9:1 Lex Adm 5-13, online: $<$ https://ejournal.unsrat.ac.id/index.php/administratum/article /view/32343>.

McKenzie, Jordi, "Graduated response policies to digital piracy: Do they increase box office revenues of movies?" (2017) 38:1 Inf Econ Policy 1-11.

Megahayati, Kemala, Muhamad Amirulloh \& Helitha Novianty Muchtar, "Perlindungan Hukum Sinematografi Terhadap Pengaksesan Tanpa Hak Oleh Pengguna Aplikasi Telegram Berdasarkan Undang-Undang Hak Cipta dan Undang-Undang Informasi dan Transaksi Elektronik di Indonesia" (2021) 5:1 Ajudikasi J Ilmu Huk 1-16.

Miguez, Pablo, "Intellectual Property and The Forced Commodification of Knowledge" (2018) 2 Univ Rev Ciencias Soc Y Humanas 41-62.

Mike, Etry, "Perlindungan Hukum Hak Kekayaan Intelektual Terhadap Tindaka Pelanggaran Pembajakan Buku Elektronik Melalui Media Online" (2019) 2:2 Al Imarah J Pemerintah dan Polit Islam 135-144.

Mulayani, S, "Pengembangan Hak Kekayaan Intelektual Sebagai Collateral (Agunan) Untuk Mendapatkan Kredit Perbankan Di Indonesia" (2012) 12:3 J Din Huk 568-578.

Nhan, Johnny, Kendra Bowen \& Aaron Bartula, "A comparison of a 
public and private university of the effects of low-cost streaming services and income on movie piracy" (2020) 60 Technol Soc 1-8.

Phau, I, "Investigating the Factors Influencing Digital Movie Piracy" (2016) 22:5 J Promot Manag 637-664.

Purba, "Pokok-Pokok Kebijakan Pembangunan Sistem HKI Nasional" (2001) 13 J Huk Bisnis.

Raharjo, Riko Sulung, M Khoidin \& Ermanto Fahamsyah, "Perlindungan Hukum terhadap Pencipta atas Pencatatan Suatu Ciptaan yang Sama" (2018) 5:3 Lentera Huk 465-482.

Setiady, Tri, "Harmonisasi Prinsip-Prinsip Trips Agreement Dalam Hak Kekayaan Intelektual Dengan Kepentingan Nasional" (2015) 8:4 FIAT JUSTISIAJurnal Ilmu Huk 595-613.

Setyowati, K, "Implementasi Sistem hak Kekayaan Intelektual (HKI)

Pada Pengelolaaan Plasma Nutfah" (2002) 8:2 Bul Plasma Nutfah 90-101.

Smith, M, "I Want You Back: The Interplay Between Legal Availability and Movie Piracy" (2019) 26:1 Int J Econ Bus 199216.

Suran Ningsih, Ayup \& Balqis Hediyati Maharani, "Penegakan Hukum Hak Cipta Terhadap Pembajakan Film Secara Daring" (2019) 2:1 J Meta Yuridis 13-32.

Vany, Arthur S De \& W David Walls, "Estimating the effects of movie piracy on box-office revenue" (2007) 30:4 Rev Ind Organ 291301.

Vernando, Wilson et al, "Pengaruh Illegal Movie Streaming Terhadap Popularitas Film Bagi Mahasiswa" (2020) 6:1 J Teknol Inf 35-42. Wibowo, Tangguh Okta, "Fenomena Website Streaming Film di Era Media Baru: Godaan, Perselisihan, dan Kritik" (2018) 6:2 J Kaji Komun 191-203.

Wilhelm, Claudia, "Investigating Neutralization Strategies in Digital Piracy: The Role of Content Preferences and Social Norms" (2020) 64:2 J Broadcast Electron Media 320-340.

AntaraNewscom, "Babak baru perlawanan industri film Indonesia terhadap pembajakan", (2020), online: 
<https://www.antaranews.com/berita/1826376/babak-baruperlawanan-industri-film-indonesia-terhadap-pembajakan>.

Aulia, Muhammad, "Vidio Coalition Of Indonesia Serukan Tindakan Tegas Lawan Pembajakan", (2020), online: iNews.id $<$ https://www.inews.id/finance/makro/video-coalition-ofindonesia-serukan-tindakan-tegas-lawan-pembajakan>.

Burhan, Fahmi Ahmad, "Saingi IndoXXI, Aplikasi Vidio Diunduh 5 Juta Kali di Tengah Pandemi", (2020), online: Katadata $<$ https://katadata.co.id/desysetyowati/digital/5ebd51634f3f9/sa ingi-indoxxi-aplikasi-vidio-diunduh-5-juta-kali-di-tengahpandemi $>$.

CNBC Indonesia, "Derita Industri Film RI Bila Kamu Nggak Tobat Nonton Bajakan", (2020), online: $<$ https://www.cnbcindonesia.com/tech/20210115172226-37216396/derita-industri-film-ri-bila-kamu-nggak-tobat-nontonbajakan>.

CNN Indonesia, "Bahaya Nonton Film di Situs Bajakan seperti IndoXXI", (2019), online: $<$ https://www.cnnindonesia.com/teknologi/20191220073003185-458560/bahaya-nonton-film-di-situs-bajakan-sepertiindoxxi>.

Kementerian Komunikasi dan Informatika Republik Indonesia, “22 Situs Diduga Pembajak Film Diblokir Kemenkominfo", (2015), online: <https://kominfo.go.id/content/detail/5651/22-situsdiduga-pembajak-film-diblokirkemenkominfo/0/sorotan_media>.

Kesowo, Bambang, Implementasi Undang-Undang Hak Cipta (2000). Kominfogoid, "Dalam 10 Bulan, Penonton Streaming Bajakan Menurun 55 Persen", (2020), online: $<$ https://kominfo.go.id/content/detail/27915/dalam-10-bulanpenonton-streaming-bajakan-menurun-55persen/0/sorotan_media>.

- - - "Kementerian Komunikasi dan Informatika Tentang Tugas Kominfo", online: <https://www.kominfo.go.id/tugas-dan- 
fungsi\#: :text=Tugas \%26 Fungsi Kementerian Komunikasi dan,Presiden dalam menyelenggarakan pemerintahan negara.>.

- - , "Sertifikasi Alat \& Perangkat Telekomunikasi", (2013), online:

$<$ https://www.kominfo.go.id/content/detail/3346/sertifikasialat-perangkat-telekomunikasi/0/layanan_kominfo $>$.

Plasmanto, Gresi, “Jejak Seorang Gamers Jadi Pembajak Film Keluarga Cemara", (2021), online: Liputan6.com $<$ https://www.liputan6.com/regional/read/4548779/jejakseorang-gamers-jadi-pembajak-film-keluarga-cemara>.

Safriana, Luki, "Kembali ke Bioskop dan Upaya Melawan Pembajakan di Era Internet", (2021), online: Katadata $<$ https://katadata.co.id/muchamadnafi/indepth/6062929b63666 /kembali-ke-bioskop-dan-upaya-melawan-pembajakan-di-erainternet>.

Setiaji, Hidayat, "Serupa IndoXXI, Situs Ini Punya Koleksi Melebihi Netflix!", (2019), online: CNBC Indones $<$ https://www.cnbcindonesia.com/tech/20191224185849-37125487/serupa-indoxxi-situs-ini-punya-koleksi-melebihinetflix>.

Setyawan, Ady Prawira, "Jokowi Sambut Baik Usulan Penyelamatan Industri Film Indonesia", (2021), online: Kompas.com <https:/www.kompas.com/hype/read/2021/03/10/173002966/jo kowi-sambut-baik-usulan-penyelamatan-industri-filmindonesia? page $=$ all $>$.

Suanto, Heri, “Tumbuh Pesat, Indonesia Pasar Potensial bagi Industri Film", (2019), online: Katadata $<$ https://katadata.co.id/herisusanto/berita/5e9a551515805/tumb uh-pesat-indonesia-pasar-potensial-bagi-industri-film>. 